\title{
Profitability Analysis of Paddy and Locally Milled Rice (oryza sativa L.) Marketing in the Federal Capital Territory, Nigeria
}

\author{
E. S. Ebukiba, and E. O. Ogbole
}

\begin{abstract}
The study investigated and compared the profitability of paddy and locally rice marketing in the Federal Capital Territory. Primary data was collected using pre-tested well-structured questionnaires through the adoption of multistage sampling technique. Descriptive statistics (mean, percentage and frequency) were used to analyze data for the socioeconomic characteristics of respondents and constraints of marketing both commodities in the study area while gross margin analysis was used to determine the cost and returns of marketing the commodities. The results for the socioeconomic characteristics of respondents sampled revealed that $61 \%$ and $71 \%$ of paddy and locally milled rice marketers respectively were between the ages of $31-50$ years, majority $(54 \%)$ of the respondents had attained some form of formal education, $74 \%$ and $48 \%$ of paddy and locally milled rice marketers respectively had over 11years of marketing experience while $75 \%$ of paddy rice marketers as against $45 \%$ of locally milled rice marketers belonged to a marketing association. The results for cost and returns of marketing the commodities revealed that paddy rice marketers with a total revenue of $\$ 59,965$ and gross margin of $\$ 41,711$ made $51 \%$ more profit that their locally milled rice counterparts with a total revenue and gross margin of $\$ 44,646.35$ and $\$ 20,427$ respectively. It was also revealed that marketing paddy and locally milled rice in the area were affected by challenges such as high transportation cost, unfavourable government policies, and inadequate and obsolete processing facilities. The study concludes that paddy rice marketing is more profitable in the Federal Capital Territory and thus recommends the formulation and implementation of government policies centered on marketing locally produced rice such as imposition of higher tariffs on importers and traders of imported rice as well as the provision of modern day storage facilities to facilitate storage of paddy rice.
\end{abstract}

Index Terms - profitability, rice, marketing, cost and returns.

\section{INTRODUCTION}

In developing countries of Asia and Africa, rice is a highly nutritious staple consumed in most homes. Thus, [11] reports that Asia accounts for $90 \%$ of rice produced and consumed annually around the world. Rice is also described as an important cereal which can be consumed in a variety of ways [16].

In Africa where about 33million tons of rice paddy is produced per annum [13], Nigeria has been ranked the highest rice producer. Unfortunately, rapid increase in population growth, urbanization and the shift from being a ceremonial food to being a part of daily diet in most homes overtime led to an upshot in the quantity of rice consumed in the country. Reference [27] reports that Nigeria consumes approximately 7.9 million tons of both foreign and locally produced rice per annum, indicating a deficit in supply and implying the availability of market for domestic rice producers. This justifies the description of rice as the fastest growing commodity in Nigeria's food market [4].

Paddy rice refers to unprocessed or rough rice, that is, whole grain rice with the hulls while milled rice refers to rice that has been processed that is, rice that has undergone the process of cleaning, parboiling, dehusking/dehulling, drying and so on, to produce edible grains. According to [12], Nigeria produces 9.8 million tones of paddy and 5.8million tones of milled rice per annum, which is less that the quantity consumed across the country. This deficit over the years created market for imported rice to meet up with local demands and overtime, Nigerian markets have become saturated with foreign rice.

In 2015, the President Mohammadu Buhari led administration in a move to boost domestic production banned the importation of rice in Nigeria. Although this was not effective, in 2019 the government followed through with a restriction on the provision of foreign exchange to rice importers through the Central Bank of Nigeria. This further led to an upsurge in the activities of rice smugglers through Nigeria's land borders [24] and as a result, the government closed down all land borders to limit these illegal activities. This move has now placed a rise in the demand. Despite the fact that Nigeria has the potentials to be self-sufficient in rice production owing to the fact that rice can be produced in all thirty-six (36) States and the FCT [28], rice marketing is set back by a weak marketing system and low margins owing to some of the earlier mentioned challenges such as government taxes, unfavourable policies, rice importation and price fluctuation [9], [10], [20], [29].

According to [22] agricultural marketing has its greatest and most enduring role to play in boosting food production. This emphasizes that to experience a growth in Nigeria's rice production; there is the need to foster an efficient marketing system that ensures that producers and consumers alike receive value for money. Reference [21] affirm this, stating that agricultural marketing plays a vital role in boosting production, consumption and fostering economic growth. Therefore, agricultural marketing has been widely defined as a series of activities that involve the movement of agricultural commodities from the point of production or producer through different chains and channels to the final consumer at a time, place and form desired [1], [7], [18]. 
Farmers across the country are discouraged from intensifying domestic production of rice because of the aforementioned challenges that have continued to weaken the commodity's marketing system. This therefore makes it imperative to critically assess the local rice marketing system for improved production. This in addition to the research dearth that exists in the area of comparing the profitability of paddy and locally milled in the study area justifies this study in order to investigate which of the commodities is most profitable for marketers in the area.

Therefore the following are questions that this research seeks to answer;

i) What are the socioeconomic characteristics of paddy and locally milled rice marketers in FCT?

ii) How profitable is the marketing of paddy and locally milled rice in FCT?

iii) What are the constraints in marketing paddy and locally milled rice in the FCT?

The broad objective of the study is to estimate the profitability of paddy and locally milled rice marketing in the Federal capital Territory. The specific objectives are;

i) To examine the socioeconomic characteristics of paddy and locally milled rice marketers in FCT;

ii) To estimate the costs and returns of paddy and locally milled rice marketing in FCT and;

iii) To determine the constraints of marketing paddy and locally milled rice in FCT.

\section{LITERATURE REVIEW}

\section{A. Market and Marketing}

Reference [2] as cited by [23] defined a market as "an area in which exchange can take place, as well as the people living there who have the means and desire to buy a product". Reference [14] as cited by [5] summarizes this definition, stating that a market "is a set of actual and potential buyers of a product". [5] added that "a market can spring up around a product, service or anything of value to the participants"; citing an example of the creation of money market as a result of people's need to either save, lend, borrow or invest funds as the case may be. A market is a system made up of activities and actors with a relationship - private individuals, governments, and institutions and so on - that creates an end result that benefits these actors.

Marketing on the other hand has been defined as the sum total of all business activities involved in the production and distribution of goods and services from the point of creation to the final consumer [19]. Reference [17] also defined marketing as a system of several related structures targeted at production, distribution and consumption of goods and services. [14] views marketing as a social process which involves individuals and groups obtaining their wants and needs through creation, offering and exchange with others. Central to these definitions of marketing are activities focused on production and production decisions [6], distribution and consumption to meet the needs of individuals. Marketing involves marketing channels, chains, institutions/intermediaries, functions, costs, pricing, demand and supply and much more. It has economic, social and environment benefits to nations, institutions and individuals alike. According to [26], efficient marketing systems promote economic development by encouraging specialization and leading to output enhancement.

\section{B. Agricultural Marketing}

Agricultural marketing has been summarily defined by [7] and [1] as a performance of all activities involved in moving farm produce from the point of production to the final consumer. The concept of agricultural marketing arises as a result of the need for commodities to be transmitted from the point of production to the region of need through a system of activities, channels and actors to the final consumer. Sometimes this process of transmission involves transforming the produce into a form that is most desirable or useful to the end user and/or storage of the produce within a period to increase shelf-life. All these activities come at a cost to the farmer or supplier or agent or marketer as the case may be, in the form of transportation cost, storage cost, cost of processing, advertisements, packaging and so on, and make up agricultural marketing. Agricultural marketing encourages continuous production as it proves that the goods to be produced would be utilized rather than wasted. This is why [6] stated that in farming, decisions such as the quality of crop to be grown or livestock to be bred are marketing decisions that will ensure continuous production overtime.

\section{Local Rice Marketing in Nigeria}

The marketing chain of rice (paddy and milled alike, especially milled) is often short and has few role players. In cases where paddy is sold to be fed to livestock, rice moves from the farmer directly to buyers who now process it into livestock feed, otherwise the farmers locally process themselves and sell or sell paddy to processors who may also mill and sell or mill at a cost for wholesalers who in turn sell to other wholesalers or retailers who finally sell in bits to consumers. A livestock breeder may also decide to buy paddy from the processor and that ends the chain. In most cases where transporters are involved, they usually have little to no interest in the produce other than to move it from one point to another and make some money off the process because oftentimes, they are sent by a group of wholesalers to transport the produce to the point of milling. In Sokoto State for example, on getting to the processors, rice is milled and packaged in bags of $100 \mathrm{~kg}$ and delivered to wholesalers in an open and centralized market. These wholesalers handle about $10-15$ bags and sell to retailers in about $2-3$ bags per retailer. The retail vendors sell the commodity in big pans in open markets in communities, with a unit of measurement referred to as mudu that is about $2.5 \mathrm{~kg}$ of rice by weight [25]. This channel of marketing is similar to what applies in other parts of the country. [8] confirms this system of marketing local rice in Ebonyi State but adds that in some cases rice millers buy directly from farmers, process the rice and sell to wholesalers who in turn sell to retailers in open markets while some farmers parboil the rice, take it to millers to be processed and then sell to wholesalers. 


\section{MATERIAL AND METHODS}

\section{A. The Study Area}

The study was conducted in the Federal Capital Territory - the capital city of Nigeria. The FCT was established by Decree Number 6 of 1976 and is located at latitude $9.0765^{\circ}$ $\mathrm{N}$ and longitude $7.3986^{\circ} \mathrm{E}$. The Capital City is characterized under the savannah climatic zone and is endowed with vast arable land and natural resources like marble, clay, tin, mica and tantalite. The area supports growth of crops such as yam, maize, rice, cucumber, water melon, cowpea, sweet potatoes, and melon and so on. The Abuja Municipal Area Council (AMAC) which is one of the six (6) Area Councils and the capital of the FCT is usually a beehive of national political and administrative activities whiles the other five (5) Area Councils, namely; Gwagwalada, Kwali, Abaji, Kuje, and Bwariare characterized by farming activities.

\section{B. Data Collection and Sampling Procedure}

Primary data was collected using pretested, well-structured questionnaires distributed by adopting multistage sampling technique. The first stage involved the purposive selection of three (3) of six (6) Area Councils, namely; Kwali, Gwagwalada and Bwari Area Councils on the basis of their size and the predominance of paddy and locally milled rice marketers. The second stage involved the purposive selection of two major markets in each of these Area Councils on the basis of the population of paddy and locally milled rice marketers, while the third and final stage involved the convenient selection of respondents, as a result of the unavailability of a comprehensive and reliable list of local rice marketers in the areas. Although the intended sample size was 420 respondents that is 180 paddy rice marketers and 240 locally milled rice marketers, as a result of incomplete responses and other outliers, only data from 171 paddy rice marketers and 222 locally milled rice marketers were analyzed.

\section{Analytical Technique}

In determining the socioeconomic characteristics of paddy and locally milled rice marketers as well as the constraints of marketing paddy and locally milled rice in the FCT, descriptive statistics mainly means, frequencies and percentages was used similar to [5] and [15].

The cost and returns of marketing paddy and locally milled rice in the FCT was estimated using gross margin analysis stated as follows:

$$
\begin{gathered}
\mathrm{GM}_{(\text {paddy/locally milled rice) }}=\mathrm{TR} \\
\mathrm{TVC}_{\text {(paddy/locally milled rice) }}- \\
\end{gathered}
$$

$$
\mathrm{GM}=\text { Gross Margin of paddy/locally milled rice in }
$$

$\mathrm{TR}=$ Total Revenue of paddy/locally milled rice (Price of $50 \mathrm{~kg}$ of paddy/locally milled rice ( $\mathrm{X}$ Quantity Sold) in $\#$

TVC = Total Variable Cost of paddy/locally milled rice

\section{RESUlts AND DiscUSSIONS}

\section{A. Socioeconomic Characteristics of Paddy and Locally Milled Rice Marketers in the FCT}

According to [15] the socioeconomic characteristics of respondents directly or indirectly affect their marketing activities. Therefore, the study examined the following characteristics age, sex, marital status, level of education, household size, marketing experience, credit access and marketing association. The results for age revealed that majority (61\% and $70 \%)$ of paddy and locally milled rice marketers respectively were between the ages of $31-50$ years implying that they are young and of economic active ages. That is, they are able to contribute economically to the marketing of local rice in the area. This result is in agreement with the findings of [3], [1], and [5]. In line with apriori expectation, $97 \%$ of paddy rice marketers were male while $95 \%$ of locally milled rice marketers were female. This is considering that women are more involved in the process of milling rice while paddy rice marketers are mainly farmers who decide to sell off their produces. Majority of paddy and locally milled rice marketers (78\% and $83 \%$ respectively) in the area are married. This is expected given that majority of respondents fall within marriageable age of 31-50 years and is in agreement with the findings of [5] that reported that majority of the respondents were married.

The results for level of education shows that $54 \%$ and $50 \%$ of paddy and locally milled rice marketers respectively had attained one form of formal education or the other. These include primary, secondary and tertiary levels of education. This is expected to have a positive effect on marketing activities as education is an advantage for training and skills acquisition as well as knowledge sharing through extension agents [1]. Majority (74\% and 71\%) of paddy and locally milled rice marketers have a household size of $6-15$ persons and this could either have a positive (if household members are part of the marketing process) or negative effect (if the head of the household/respondent has to cater to the needs of other household members) on marketing the commodities. This is in agreement with the findings of [15] who reported that $70 \%$ of respondents had a household size of $6-15$ persons.

Majority $(73 \%)$ of paddy rice marketers have a marketing experience of 11years and above while only $46 \%$ of their locally milled rice counterparts have the same level of marketing experience. This is expected, given that majority of the paddy rice marketers are farmers who have been into the business for several years. Although the result for locally milled rice marketers is expected to have a negative effect on marketing as it is expected that more years of marketing experience translate to a better understanding of the marketing system and market forces. The results for credit access shows that $86 \%$ and $84 \%$ of paddy and locally milled rice marketers respectively have no access to any form of credit. This is similar to the findings of [5]. Majority (75\%) of the paddy rice marketers belonged to a marketing association while only $35 \%$ of their locally milled rice counterparts belonged to any association. This is expected considering that most paddy rice marketers are farmers who already belonged to existing farmer groups. 
TABLE 1: SOCIOECONOMIC CHARACTERISTICS OF PADDY AND LOCALLY MILLED RICE MARKETERS IN THE FCT

\begin{tabular}{|c|c|c|c|c|}
\hline \multirow{2}{*}{ Variables } & \multicolumn{2}{|c|}{ Paddy Rice } & \multicolumn{2}{|c|}{ Locally Milled Rice } \\
\hline & $\mathbf{F}$ & $\%$ & f & $\%$ \\
\hline \multicolumn{5}{|l|}{ Age (Years) } \\
\hline \multirow{2}{*}{$\begin{array}{l}20-30 \\
31-40\end{array}$} & 19 & 11.1 & 24 & 10.8 \\
\hline & 39 & 22.8 & 75 & 33.8 \\
\hline $41-50$ & 77 & 45.0 & 85 & 38.3 \\
\hline $51-60$ & 35 & 20.5 & 34 & 15.3 \\
\hline $61-70$ & 1 & 0.6 & 4 & 1.8 \\
\hline Mean Age & & & $42.4 \mathrm{yrs}$ & \\
\hline \multicolumn{5}{|l|}{ Sex } \\
\hline Male & 5 & 2.9 & 211 & 95.0 \\
\hline Female & 166 & 97.1 & 11 & 5.0 \\
\hline \multicolumn{5}{|l|}{ Marital Status } \\
\hline Single & 38 & 22.2 & 21 & 9.5 \\
\hline Married & 133 & 77.8 & 185 & 83.3 \\
\hline Divorced & & & 10 & 4.5 \\
\hline Divorced & & & 2 & 0.9 \\
\hline Widow & & & 4 & 1.8 \\
\hline \multicolumn{5}{|c|}{ Level of Education } \\
\hline $\begin{array}{l}\text { No Formal } \\
\text { Education }\end{array}$ & 79 & 46.2 & 103 & 46.4 \\
\hline $\begin{array}{l}\text { Primary } \\
\text { Education }\end{array}$ & 27 & 15.8 & 25 & 11.3 \\
\hline $\begin{array}{l}\text { Secondary } \\
\text { Education }\end{array}$ & 43 & 25.1 & 68 & 30.6 \\
\hline $\begin{array}{l}\text { Tertiary } \\
\text { Education }\end{array}$ & 22 & 12.9 & 26 & 11.7 \\
\hline \multicolumn{5}{|l|}{ Household Size } \\
\hline$<6$ & 31 & 18.1 & 57 & 25.7 \\
\hline $6-10$ & 94 & 55.0 & 129 & 58.1 \\
\hline $11-15$ & 34 & 19.9 & 30 & 13.5 \\
\hline $16-20$ & 10 & 5.8 & 6 & 2.7 \\
\hline $21-25$ & 2 & 1.2 & & \\
\hline \multicolumn{5}{|c|}{ Marketing Experience (Years) } \\
\hline$<11$ & 46 & 26.9 & 116 & 52.3 \\
\hline $11-20$ & 62 & 36.3 & 80 & 36.0 \\
\hline $21-30$ & 51 & 29.8 & 24 & 10.8 \\
\hline $31-40$ & 10 & 5.8 & 2 & 0.9 \\
\hline $41-50$ & 2 & 1.2 & & \\
\hline \multicolumn{5}{|l|}{ Credit Access } \\
\hline No Access & 148 & 86.5 & 188 & 84.7 \\
\hline Access & 23 & 13.5 & 34 & 15.3 \\
\hline \multicolumn{5}{|c|}{ Marketing Association } \\
\hline No membership & 43 & 25.1 & 144 & 64.9 \\
\hline Membership & 128 & 74.9 & 78 & 35.1 \\
\hline $\mathrm{N}$ & & & & \\
\hline
\end{tabular}

Source: Field Survey, 2019.
B. Costs and Returns of Paddy and Locally Milled Rice Marketing in FCT

The results of the gross margin analysis of paddy and locally milled rice marketing in the Federal Capital Territory are as shown on Table 2. The total revenue for paddy rice marketers was $\$ 59,965$ with a total variable cost of $\$ 18,254$ Based on this, the gross margin of paddy rice marketers sampled stood at $\$ 41,711$ considering that Fixed Cost in negligible in the short run and in gross margin analysis. In comparing these results with findings from locally milled rice marketers, the total revenue for locally milled rice marketers stood at $\$ 44,646$ with a total variable cost of $\$ 24,218$ and a gross margin of $\$ 20,427$. It was therefore, concluded that paddy rice marketers have a profit margin which is about $51.02 \%$ higher than that of locally milled rice marketers. This is a deviation from the apriori expectation, considering that it was expected that the benefits of value addition would increase the revenue generated by locally milled rice marketers.

TABle 2: Costs And Returns OF PAdDy And Locally Milled Rice MARKETING IN THE FCT

\begin{tabular}{lcc}
\hline \multicolumn{1}{c}{ Variable } & $\begin{array}{c}\text { Paddy Rice } \\
\text { Marketers }\end{array}$ & $\begin{array}{c}\text { Locally Milled } \\
\text { Rice Marketers }\end{array}$ \\
\hline Total Revenue (TR) (Naira) & $59,965.49$ & $44,646.35$ \\
Total Variable Cost (TVC) & $18,254.44$ & $24,218.57$ \\
(Naira) & $41,711.05$ & $20,427.78$ \\
Gross Margin (GM) (Naira) & 171 & 222 \\
\hline $\mathrm{N}$ & \\
\hline ***TR = P X Q; TVC = TC - TFC; GM = TR - TVC & \\
***Fixed Cost in negligible in the short run & \\
Source: Field Survey, 2019.
\end{tabular}

\section{Constraints of Marketing Paddy and Locally Milled Rice in FCT}

The constraints of marketing locally produced rice in Nigeria are similar across different States as reported by different studies [9], [10], [20], [18]. Results from this study revealed that these challenges are no different in the FCT and are shown in Table 3 where majority of the respondents identified poor market infrastructure, high transportation cost, poor storage facilities and inadequate/obsolete processing facilities as some of the constraints in marketing paddy and locally milled rice in the area.

TABLE 3: Constraints Of MARKeting PADDy And Locally Milled Rice In The FCT

\begin{tabular}{|c|c|c|c|c|c|c|c|c|c|c|c|c|}
\hline \multirow[b]{2}{*}{ Constraint } & \multicolumn{6}{|c|}{ Paddy Rice } & \multicolumn{6}{|c|}{ Locally Milled Rice } \\
\hline & $\begin{array}{c}\text { Strongly } \\
\text { Agree } \\
\end{array}$ & Agree & Disagree & $\begin{array}{l}\text { Strongly } \\
\text { Disagree } \\
\end{array}$ & $\begin{array}{l}\text { Mean } \\
\text { Score } \\
\end{array}$ & SD & $\begin{array}{c}\text { Strongly } \\
\text { Agree } \\
\end{array}$ & Agree & Disagree & $\begin{array}{l}\text { Strongly } \\
\text { Disagree }\end{array}$ & $\begin{array}{l}\text { Mean } \\
\text { Score } \\
\end{array}$ & SD \\
\hline Poor market infrastructure & $57(33.3)$ & $90(52.6)$ & $10(5.8)$ & $14(8.2)$ & 3.11 & 0.843 & $102(45.9)$ & $83(37.4)$ & $25(11.3)$ & $12(5.4)$ & 3.24 & 0.857 \\
\hline High transportation cost & $33(19.3)$ & $123(71.9)$ & $13(7.6)$ & $2(1.2)$ & 3.09 & 0.556 & $61(27.5)$ & $118(53.2)$ & $39(17.6)$ & $4(1.8)$ & 3.06 & 0.722 \\
\hline Poor storage facilities & $27(15.8)$ & $113(66.1)$ & $31(18.1)$ & - & 2.98 & 0.584 & $69(31.1)$ & $117(52.7)$ & $35(15.8)$ & $1(0.5)$ & 3.14 & 0.684 \\
\hline $\begin{array}{l}\text { Inadequate/Obsolete } \\
\text { Processing Facilities }\end{array}$ & $34(19.9)$ & $121(70.8)$ & $16(9.4)$ & - & 3.11 & 0.532 & $53(23.9)$ & $142(64.0)$ & $23(10.4)$ & $4(1.8)$ & 3.10 & 0.638 \\
\hline High handling costs & $23(13.5)$ & 143 (83.6) & - & - & 3.11 & 0.392 & $48(21.6)$ & $152(68.5)$ & $22(9.9)$ & - & 3.12 & 0.550 \\
\hline Packaging problems & $20(11.7)$ & $118(69.0)$ & $31(18.1)$ & $2(1.2)$ & 2.91 & 0.583 & $55(24.8)$ & $130(58.6)$ & $33(14.9)$ & $4(1.8)$ & 3.06 & 0.683 \\
\hline $\begin{array}{l}\text { Grading and } \\
\text { standardization problems }\end{array}$ & $24(14.0)$ & $140(81.9)$ & $7(4.1)$ & - & 3.10 & 0.415 & $70(31.5)$ & $134(60.4)$ & $18(8.1)$ & - & 3.23 & 0.586 \\
\hline Poor marketing facilities & $53(31.0)$ & $113(66.1)$ & $5(2.9)$ & - & 3.28 & 0.512 & $117(52.7)$ & $79(35.6)$ & $25(11.3)$ & $1(0.5)$ & 3.41 & 0.704 \\
\hline Market intelligence & $15(8.8)$ & $100(58.5)$ & $56(32.7)$ & - & 2.76 & 0.599 & $72(32.4)$ & $112(50.5)$ & $35(15.8)$ & $3(1.4)$ & 3.14 & 0.720 \\
\hline $\begin{array}{l}\text { Poor management of } \\
\text { market }\end{array}$ & $32(18.7)$ & $125(73.1)$ & 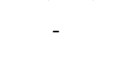 & - & 3.11 & 0.509 & $70(31.5)$ & $130(58.6)$ & $21(9.5)$ & $1(0.5)$ & 3.21 & 0.620 \\
\hline $\begin{array}{l}\text { Charges by market tax } \\
\text { force }\end{array}$ & $34(19.9)$ & $120(70.2)$ & $17(9.9)$ & - & 3.10 & 0.539 & $36(16.2)$ & $155(69.8)$ & $29(13.1)$ & $2(0.9)$ & 3.01 & 0.575 \\
\hline Low pricing & $11(6.4)$ & $127(74.3)$ & $29(17.0)$ & $4(2.3)$ & 2.85 & 0.553 & $46(20.7)$ & $144(64.9)$ & $26(11.7)$ & $6(2.7)$ & 3.04 & 0.658 \\
\hline Activities of middle men & $25(14.6)$ & $99(57.9)$ & $41(24.0)$ & $6(3.5)$ & 2.84 & 0.709 & $69(31.1)$ & $119(53.6)$ & $31(14.0)$ & $3(1.4)$ & 3.14 & 0.697 \\
\hline $\begin{array}{l}\text { Unfavourable government } \\
\text { policies }\end{array}$ & $46(26.9)$ & $82(48.0)$ & $43(25.1)$ & & 3.02 & 0.723 & $90(40.5)$ & $93(41.9)$ & $37(16.7)$ & $2(0.9)$ & 3.22 & 0.562 \\
\hline
\end{tabular}

Source: Field Survey, 2019. 


\section{CONCLUSION}

The study concludes that paddy rice marketers have a higher profit margin than locally milled rice marketers in the FCT. High transportation cost, unfavourable government policies, poor market intelligence, grading and standardization problems as well as inadequate storage facilities and obsolete processing facilities were found to be challenges faced by paddy and locally milled rice marketers alike. In view of this, the study therefore recommends the following: Considering the profit margin between paddy and locally milled rice marketers, marketers are encouraged to engage more in paddy rice marketing as it was found to be about $51 \%$ more profitable than locally milled rice in the area. Local rice marketers are encouraged to join market associations as this will greatly facilitate knowledge sharing such as information on latest trends like preferred packaging as well as create easy access to credit facilities and other government or private sector provided incentives therefore enhancing their marketing efficiency. It is also recommended that further studies investigate the relationship between storage and profit margin of paddy rice.

\section{REFERENCES}

[1] Abah, D. A., Anjeinu, G. A. \& Iorhon, P. A (2015): Analysis of Performance of Paddy Marketing in Benue State, Nigeria. Journal of Agricultural Science and Engineering, 1 (3); 143 - 152.

[2] Abbott, J.C., \&Makeham, J.P (1981): Agricultural Economics and Marketing in the tropics.

[3] Agwu, N. M. \& Ibeabuchi, J.O. (2011). Socio-Economic Analysis of Wholesale Rice Marketers in Abia State, Nigeria, International Journal of Social Science and Humanity, 1(4); 285-289.

[4] Akande, T. (2003): An Overview of Nigerian Rice Economy. Retrieved from http://www.unep/etu/etp/events/agriculture/nigeria.pdf.

[5] Anthony, C. N. \& Anyalor, M. (2019): Marketing Analysis of Locally Produce Rice in Abakaliki Local Government Area of Ebonyi State, Nigeria. Mediterranean Journal of Social Sciences, 10 (1), $39-47$.

[6] Asogwa, B. C. \&Okwoche, V. A. (2012): Marketing of Agricultural Produce among Rural Farm Households in Nigeria: The Case of Sorghum Marketing in Benue State. International Journal of Business and Social Science, 3 (13); 269 -277.

[7] Bassey, N. E., Ibok,O. W. \&Akapaeti, A. J. (2013): Rice Market Structure, Conduct and Performance in Nigeria: A Survey of Akwalbom State Rice Marketers. Asian Journal of Agriculture and Food Science, 1 (3); $102-111$.

[8] Chidiebere-Mark, N. M. (2017): Analysis of Value Chain in Rice Production Systems in Ebonyi State, Nigeria. A Doctor of Philosophy Thesis submitted to the Department of Agricultural Economics, Federal University of Technology, Owerri.

[9] Dauna, Y., Giroh, D. Y., \&Adamu, W. B. (2018): Analysis of the structure and Performance of paddy rice marketing in Adamawa State, Nigeria. Agricultural Science and Technology, 10 (2); $174-177$.

[10] Emeka, N. \&Ugwu, J. N. (2015): Economic Viability of Processing and Marketing of Rice in Uzouwani Local Government Area of Enugu State, Nigeria. Developing Country Studies, 5 (17); 111 - 114.

[11] Food and Agriculture Organization of the United Nations (2016) Bridging the Rice Yield Gap in the Asia - Pacific Region. A report submitted at an Expert Consultation.

[12] Food and Agriculture Organization of the United Nations (2017): Food and Agriculture Organization of the United Nations Statistics.

[13] Food and Agriculture Organization of the United Nations (2018): Food and Agriculture Organization of the United Nations Statistics.

[14] Kotler, P. (2003): Marketing management. Eleventh Edition. Pearson Education, Inc. USA.

[15] Madu, A. B. and Aniobi, U. J. (2018): Profitability Analysis of Paddy: A Case of Agricultural Zone 1 Niger State, Nigeria. Journal of Bangladesh Agricultural University, 16 (1), 88 - 92.

[16] Madugu, A. J., Moses, J. D., \& Zalkuwi, J. W. (2017): Economics of Rice Production in Mubi-North Local Government Area of Adamawa
State, Nigeria. IOSR Journal of Agriculture and Veterinary Science, 10 (2), $62-65$.

[17] Mendoza, G. (1995): A Primer on Marketing Channels and Margins Prices, Products and People: Analyzing Agricultural Markets in Developing Countries. Lynne Reinner Publishers, Boulder, London. 498.

[18] Nwaobiala \& Adesope(2011): Economic Analysis of Small-holder Rice Production Systems in Ebonyi State, South East - Nigeria. Russian Journal of Agricultural and Socio-Economic Sciences, 11(23).

[19] Nwele, J. O. (2016): Economics of Rice Production and Marketing in Nigeria: A Study of Ebonyi State. International Journal for Research in Business, Management and Accounting 2(5); 17-37.

[20] Oyewo, I. O., Oladipupo-Alade, E. O., Oke, O. O., Ademuwagun, A. A., \&Alabi, R. T. (2017): Economic Analysis of Rice Marketing in Ibadan North Local Government Area, Oyo State - Nigeria. Conference Proceedings of the $18^{\text {th }}$ Annual National Conference of the Nigeria Association of Agricultural Economists held $16^{\text {th }}-19^{\text {th }}$ October, 2017.

[21] Rao, D. V. S., Rao, D. V. S. and Reddy, S. B. P. (2012): Agricultural Marketing. Lecture Notes Course No; AECO341.Retrieved fromhttp://www.angrau.ac.in/media/1638/AECO\%20341.pdf.

[22] Saravanakumar, V. \& Kiruthika, N. (2015): Economic Analysis of Production and Marketing of Paddy in Tamil Nadu. International Research Journal of Agricultural Economics and Statistics. 6 (2); 249 255.

[23] Takele, A. (2010): Analysis of Rice Profitability and Marketing Chain: The Case of Fogera Wodera, South Gondar Zone, Amhara Regional State, Ethiopia. An Msc Thesis submitted to the College of Agricultural Economics, Haramaya University, Ethiopia.

[24] The Guardian Newspaper (2019): Nigeria: Porous Borders, Unending Rice Smuggling Weighs On Local Production. A news report on May $29^{\text {th }}$, 2019. Available on https://allafrica.com/stories/201905290464.html.

[25] Tinsley, R. D. (2012): Rice Value Chain Analysis - Sokoto State Nigeria. A Consultant Report put together for Winrock International on the request of IFAD-CBARDP.

[26] Tura, V. B., Jonathan, A. and Lawal, H. (2010). Structural Analysis of Paddy Rice Markets in Southern Part of Taraba State, Nigeria. Journal of Agriculture and Social Sciences, 6 (4); 110 -112.

[27] Udemezue, J. C. (2018): Analysis of Rice Production and Consumption Trends in Nigeria. Journal of Plant Sciences and Crop Production, 1 (3) $305-310$.

[28] Ugalahi,B. U., Adeoye S. O. \&Agbonlahor M. U. (2016): Irrigation Potentials and Rice Self-Sufficiency in Nigeria: Review. African Journal of Agricultural Research, 11 (5); 298 -309.

[29] Ugwu, E. \&Adepetun, A. (2008): Food Prices Crashes': Nigeria Braces Up. The Guardian, 27. 